\title{
GENERAL PUBLIC AWARENESS IN LIFE INSURANCE
}

\section{Phadindra Kumar Paudel* and Apresha Silwal}

\begin{abstract}
This survey aimed at ascertaining the views of 120 respondents from overall sectors on the factors that determine the awareness in life insurance in the context of Nepal. The result of insurance awareness hypothesis shows that education is an important factor which affects the buying decision of consumers in life insurance. The researcher has employed descriptive design to conduct the study through structured set of questionnaire; convenience sampling technique has been used in the initial stage to narrow down the population from entire population. Similarly likert scale has been used for consumer survey and later computed using statistical package for social science (SPSS) Version 20 for windows to compare means. The survey result produces the result that in spite of the immense benefits and security provided by the life insurance, public awareness regarding it is low. The research also provides light in the aspect that insurance awareness is positively affected by educational level of attainment whereas it is statistically independent to gender, income and professional line of involvement.
\end{abstract}

Key words: Life insurance, education, awareness, gender, professional

\footnotetext{
*Senior faculty of Financial Accounting, Nepal College of Management, Kathmandu University, email: phadindrakumar.paudel@ncm.edu.np, corresponding author: apraysha@gmail.com
} 


\section{INTRODUCTION}

One of the personal risks that troubles human mind is the risk of premature death. In other words, no one wants to die (Schendler, 2005). Another scholar argued that the cost of premature death is huge because the family will lose its share of income holder, and at the same time, several expenses are incurred such as funeral expenses, medical bills and settlement cost and decline in standard of living due to the inadequate income (Rejda, 2011).Hence, life insurance provides individuals the facility to share the risk of premature death and to minimize the financial loss from the death of family head Dar (2011) has claimed. On studying the determinants of aggregate life insurance demand, Li, Moshirian, Nguyen and Wee (2007) have analyzed in a cross-section of developed countries and the study has revealed that the demand for life insurance increases with the number of dependent members in the family. So, the cost of premature death is even higher to those family members with many dependents and for such families, life insurance is a must.

As people are recognizing the benefits of life insurance, Browne and Kim (1993) have argued that the world of life insurance business has grown drastically in the last 10 years. These scholars have assessed the role of various factors that lead to variations in the demand for life insurance worldwide and have concluded that life insurance is positively correlated to income, education and number of dependent members in the family and negatively correlated to inflation, life expectancy and national expenditure on social security.

Dar (2011) has assessed the level of general public awareness and sources of information of the life insurance in the state of Jammu and Kashmir in India. In this study, various factors determining awareness such as religion, type of family, occupation, family income, educational and social status etc. have been analyzed and the study has claimed providing financial protection as the driving public perception on buying life insurance. Similarly, in Jain and Goyal (2012), the study has attempted to identify the aspects that the people have heard about the life insurance and it also has revealed that there was lack of knowledge of different aspects of insurance and it also has been suggested that the government needs to create appropriate awareness regarding the insurance products and services that are offered by the insurance companies in order to fulfill the needs and demand of the general public. 
Gurung (2012) has attempted to link the insurance as an essential security element attached with human life stating that human life is precious with the fact that nobody in the world wants to die but the reality is that everyone has to die someday. This scholar has further added that when somebody dies, stress in the family increases not only because of missing the loved one but also for spending the many costs associated to such incident whereby such costs would further mount in case when the main earner of the family has passed out. Finally, this scholar has advised that life insurance does not only serve as a financial security seal to make sure that the family becomes capable of paying debt in the income holder's absence, but also if somebody wants to invest for future purpose, it can be a good option to get the appropriate value of money.

In spite of the immense benefits of life insurance, only a few percentages of Nepalese are actually practicing it which is affecting the life insurance industry's growth. Hence, this research is conducted with the major focus to provide an overview of the level of awareness of life insurance. The researcher also focused on several factors determining the awareness of life insurance.

\section{REVIEW OF LITERATURE}

Insurance covers very important role in today's business world which has automatically led to the evolution of several types of insurance and its growth. Insurance act,1992 has stated "Life Insurance Business is a business relating to a contract regarding to the life of any person under which he/she or his/her heir in the event of his/her death, will be paid a particular amount in case a specified amount is paid in installment on the basis of his/her age"

Kakar and Shukla (2010) have claimed that the demand for life insurance has experienced a rapid growth in the last few decades. These scholars have evaluated the several determinants of demand for life insurance in both rural and urban areas separately. In rural areas, occupation has strong effect on life insurance whereas the household with more educated members show a higher level of involvement in insurance business. Further, in the urban context, households having alternative source of income and those who focused on long term saving needs shows a higher level of involvement.

Sastry (2010) has stated that various factors such as sound economic fundamentals, a rising middle class, an improving regulatory framework, and rising risk awareness are giving birth 
to the rapid growth in the Indian life insurance market. Raju and Mohan (2011) have observed that nowadays customers are getting educated by media and are always in search of the best product quality and brand name. The researchers further indicated that awareness has improved consumer awareness aspects relating to life insurance product.

Dar (2011) asserts that the awareness about insurance is low but the role of media in creating awareness is high. Thus, the scholar focuses on the aspect that insurance companies should target general people, by awareness campaigns like radio and television advertisements. $\mathrm{He}$ finally claimed that as long as people do not perceive life insurance as a major factor to influence their life, growth in insurance does not take place, for which, appropriate insurance policy needs to be developed that is accessible, available, affordable and acceptable to all sections of the society.

\section{RESEARCH METHODOLOGY}

In the survey, the researcher had used both primary and secondary sources of information for the empirical and conceptual understanding. Primary data are observed or collected directly for the first time and secondary data are collected by someone other than the user. As a primary data the researcher had collected the primary data using survey questionnaires to which the respondents will respond. Likewise, from secondary sources, the present researcher had reviewed various books, journals, articles and various published documents of various scholars and institutions.

\section{A. Sample selection and responses retrieved}

The survey was conducted by distributing 225 questionnaires to the general public from Kathmandu valley. Only 120 responses were obtained, out of which 24 responses were from respondent up to SLC level educational attainment, 20 from Intermediate level, 50 from bachelors, 20 from Masters and 6 from others. The sampling frame determined for survey of general public on educational level of attainment and responses retrieved is presented in table 1 . 
Table 1.1: Sampling frame for survey of general public awareness in life insurance and responses retrieved

This table reveals the sampling frame and responses retrieved for survey of general public awareness in life insurance. Although, total number of proposed respondents was 225, only 120 responses were obtained.

\begin{tabular}{|l|l|l|r|}
\hline Group & $\begin{array}{l}\text { Proposed } \\
\text { Respondent }\end{array}$ & $\begin{array}{l}\text { Number of responses } \\
\text { received }\end{array}$ & \multicolumn{1}{|l|}{ Response rate } \\
\hline Up to SLC & 45 & 24 & 53.33 \\
\hline Intermediate & 45 & 20 & 44.44 \\
\hline Bachelors & 60 & 50 & 83.33 \\
\hline Masters & 35 & 20 & 57.14 \\
\hline Others & 40 & 6 & 15.00 \\
\hline Total & 225 & 120 & 53.33 \\
\hline
\end{tabular}

Source: Questionnaire Survey 2016

\section{B. Statistical Tools Used}

\section{i. $\quad$ Composite mean and rank}

Likert scale questionnaire is distributed to the respondents and asked to rate each variables they agree influence life insurance awareness. Respondents are asked to rank on a scale from 5 to 1 , where 5 indicates strongly agree, 4 indicates agree, 3 indicates very less likely agree, 2 indicates disagree and 1 indicates strongly disagree. The mean weight is used in this study to analyze the primary data and draw inferences from them. The degree of importance of each value to the overall total is measured by mean weight. Mean weights are calculated to rank the issues, raised on questionnaire based on their importance as mentioned by the respondents.

\section{ii. Regression and correlation analysis}

In this study, econometric models as given below have been used to describe insurance awareness among general public. This model is employed to confirm the relationship between independent variable and dependent variable. Dependent variable is life insurance awareness whereas independent variables are gender, income, education and profession. The theoretical model of this study maybe framed here as under:

Life insurance awareness $=\alpha+\beta 1($ Gender $)+\beta 2($ Income $)+\beta 3($ Education $)+\beta 4($ Profession $)+\in i$ 


\section{Respondents profile}

A general consumer survey was conducted to find out public awareness in life insurance. With a view to obtain precise information on life insurance awareness, general public from all levels are given to fill the questionnaire. A total 225 questionnaires were distributed out of which only 120 were received so the response rate is $53.35 \%$. The initial part of the questionnaire has been included general background of the respondents' survey. The questionnaire contained the questions relating to the gender, age, education, profession and income of the respondents. The general background of the respondents is presented in the table 1.2 and figure in annexure 2 (Panel A, B, C, D, and E).

As regard of the gender of the participants, the majority of the respondents are male representing $54.2 \%$ of total respondents followed by female respondents representing $45.8 \%$. Similarly, table $1.2 \mathrm{~B}$ provides the information regarding age of the respondents. Out of total respondents, 35 respondents $(29.2 \%)$ are from the age group 2025, followed by 27 respondents (22.5\%) from age group 26-30, 25 respondents (20.8\%) above age 41, 17 respondents (14.2\%) from age group 31-35 and 16 respondents (13.3\%) from the age group 36-40.

The survey questionnaire also contained the educational level of attainment of the respondents, the majority lies in the bachelors with $50(41.7 \%)$ respondents, followed by Up to SLC with 24 (20\%) respondents, Intermediate level with $20(16.7 \%)$ respondents and Masters level with $20(16.7 \%)$ and others with $6(5 \%)$. As evident from table 1.2D, the survey shows the professional level of attainment of the respondents where majority lies in the Private service with $29(24.2 \%)$ followed by students, home maker, self-employed, public service, freelancer and others with 25 (20.8\%), 19 (15.8\%), 19 (15.8\%), 15 (12.5\%), $7(5.8 \%)$ and $6(5 \%)$.

The table 1.2E shows the income level of the respondents where maximum respondents of $51(42.5 \%)$ are from income level up to 25,000, followed by 40 (33.3\%) from 25,000 50,000 then 18 (15\%) from 50,000-75,000, 6 (5\%) from 100,000 and above, and minimum respondents of $5(4.2 \%)$ from $75,000-100,000$. 
Table 1.2: Respondent's Information

Here, for the data analysis and presentation the researcher has presented the following details of the respondent information.

\begin{tabular}{|c|c|c|c|}
\hline A. & Gender & Frequency & Percentage \\
\hline & Male & 65 & 54.2 \\
\hline & Female & 55 & 45.8 \\
\hline & Total & 120 & 100 \\
\hline \multirow[t]{7}{*}{ B } & Age of the respondents & & \\
\hline & $20-25$ & 35 & 29.2 \\
\hline & $26-30$ & 27 & 22.5 \\
\hline & $31-35$ & 17 & 14.2 \\
\hline & $36-40$ & 16 & 13.3 \\
\hline & Above 41 & 25 & 20.8 \\
\hline & Total & 120 & 100 \\
\hline \multirow[t]{7}{*}{$\mathrm{C}$} & Education of respondents & & \\
\hline & Up to SLC & 24 & 20 \\
\hline & Intermediate level & 20 & 16.7 \\
\hline & Bachelors & 50 & 41.7 \\
\hline & Masters & 20 & 16.7 \\
\hline & Others & 6 & 5 \\
\hline & Total & 120 & 100 \\
\hline \multirow[t]{9}{*}{$\mathrm{D}$} & Profession of respondents & & \\
\hline & Home maker & 19 & 15.8 \\
\hline & Self- employed & 19 & 15.8 \\
\hline & Private service & 29 & 24.2 \\
\hline & Public service & 15 & 12.5 \\
\hline & Freelancer & 7 & 5.8 \\
\hline & Student & 25 & 20.8 \\
\hline & Others & 6 & 5 \\
\hline & Total & 120 & 100 \\
\hline \multirow[t]{7}{*}{ E } & Income of respondents & & \\
\hline & Up to 25,000 & 51 & 42.5 \\
\hline & $25,000-50,000$ & 40 & 33.3 \\
\hline & $50,000-75,000$ & 18 & 15 \\
\hline & $75,000-100,000$ & 5 & 4.2 \\
\hline & 100,000 and above & 6 & 5 \\
\hline & Total & 120 & 100 \\
\hline
\end{tabular}




\section{SURVEY FINDINGS}

On the basis of overall data presentation and analyses above, the researcher came up with the different findings which further assisted in making the conclusion of the research. The table below shows the gender wise display of level of insurance awareness from various media in the general public.

Table 1.3: Gender and awareness of Insurance from different Media

\begin{tabular}{|c|c|c|c|c|c|c|c|c|c|c|c|c|}
\hline \multirow{3}{*}{ Gender } & \multicolumn{10}{|c|}{ Awareness of Insurance From Different Media } & \multirow{2}{*}{\multicolumn{2}{|c|}{ Total }} \\
\hline & \multicolumn{2}{|c|}{$\begin{array}{l}\text { Advertiseme } \\
\text { nt }\end{array}$} & \multicolumn{2}{|c|}{ Agent } & \multicolumn{2}{|c|}{$\begin{array}{l}\text { Recommendati } \\
\text { on }\end{array}$} & \multicolumn{2}{|c|}{$\begin{array}{l}\text { Social } \\
\text { Network } \\
\text { ing Sites }\end{array}$} & \multicolumn{2}{|c|}{ Others } & & \\
\hline & $\mathrm{N}$ & $\%$ & $\mathrm{~N}$ & $\%$ & $\mathrm{~N}$ & $\%$ & $\mathrm{~N}$ & $\%$ & $\mathrm{~N}$ & $\%$ & $\mathrm{~N}$ & $\%$ \\
\hline Male & 51 & 53. & 27.00 & 48.2 & 31.0 & 47. & 0 & 0 & 4 & 44.4 & 113 & 49.78 \\
\hline Female & 45 & 46. & 29.00 & 51.7 & 34.0 & 52. & 1 & 1 & 5 & 55.5 & 114 & 50.22 \\
\hline Total & 96 & 100 & 56 & 100 & 65 & 10 & 1 & 1 & 9 & 100 & 227 & 100 \\
\hline
\end{tabular}

The information presented in the above table 1.3 unveils that out of the total respondents in the survey, majority lies in the male respondents since they are aware about insurance through advertisement by $53.12 \%$ and female respondents by $46.87 \%$. In agent as a awareness media, majority lies in female respondents by $51.7 \%$ then the male by $48.2 \%$. Similarly, from the recommendation of friends and family, a total of $52.30 \%$ of females and $47.70 \%$ of males are aware about insurance. It is shown, from the above study that $100 \%$ of females are aware about life insurance through social networking sites beating male to $0 \%$. Likewise, from other several media $55.55 \%$ of females and $45.45 \%$ of males are aware about insurance. So in overall majority lies in the females, since they are aware about insurance by $50.22 \%$ whereas males are aware about it by $49.78 \%$.

\section{Table 1.4: Test of Equality}

\begin{tabular}{|r|l|r|r|r|l|l|}
\hline \multicolumn{7}{|c|}{ ANOVA } \\
\hline Model & & Sum of Squares & Df & Mean Square & F & Sig. \\
\hline 1 & Regression & 2.776 & 4 & 0.694 & 2.965 & $.023 \mathrm{~b}$ \\
\hline & Residual & 26.924 & 115 & 0.234 & & \\
\hline & Total & 29.7 & 119 & & & \\
\hline
\end{tabular}

This table above reveals that the overall model is fit. The larger the $\mathrm{F}$ ratio the more likely the model is significant and that there are significant differences between group 
means. A small $\mathrm{F}$ ratio close to 1 implies that there is no significant difference between means. The $\mathrm{P}$ value 0.023 is less than 0.05 which indicates that the group of independent variables has significant impact on life insurance awareness.

Whereas the table below shows the Regression results of life insurance survey 2016. The $\mathrm{T}$ - values of each regression coefficients are provided to have the information regarding significance of the coefficients of the independent variables such as Gender, Income level, Education and Profession and dependent variable as life insurance awareness.

Table 1.5: Determinants of life insurance awareness

\begin{tabular}{|l|c|c|}
\hline \multirow{2}{*}{\multicolumn{1}{|c|}{ Constant }} & Coefficient & P-value \\
\cline { 2 - 3 } & 1.613 & 0.00 \\
\hline Gender & $(8.311)$ & 0.19 \\
\hline & 0.118 & \\
\hline Income level & $(1.318)$ & 0.913 \\
\hline & -0.005 & 0.004 \\
\hline Education & $(0.11)$ & \\
\hline & -0.127 & 0.848 \\
\hline Profession & $(2.979 *)$ & \\
\hline
\end{tabular}

Figures in the parenthesis are t- statistics, * significant at $1 \%$ level of significance

The information projected in the table discloses that the calculated value of significance of gender is greater than 0.05 . With this statistical confirmation it can be claimed that there may not be statistically significant relationship between gender and life insurance awareness. Hence, the null hypothesis is not rejected. Similarly, the table shows the level of significance in income is more than 0.05 which confirms that the null hypothesis is not rejected. Therefore, we conclude that income and insurance awareness may be significantly independent of each other.

The level of significance in education is less than 0.05 which confirms that the null hypothesis is rejected. Therefore, we conclude that literacy status and life insurance 
awareness may be significantly dependent of each other. Likewise, in the professional line of involvement, the table discloses that the calculated value of significance is 0.848 which is greater than 0.05 . With this statistical confirmation, it can be claimed that occupation and insurance awareness are statistically independent of each other. Thus, we do not reject the null hypothesis. 
Similarly, following two tables shows the result of rating scale that has been used in the questionnaire. The table 1.6 displays different criteria under communication and advocacy along with their mean value and ranking. The mean score is calculated as follows:

Mean value $=(5.8 * 1+4.2 * 2+10 * 3+43.3 * 4+36.7 * 5) / 100$, and so on.

Table 1.6: Measurement of Communication and Advocacy

\begin{tabular}{|l|r|r|r|r|r|r|r|}
\hline & \multicolumn{9}{|c|}{ Percentage of response within each } & & \\
\hline $\begin{array}{l}\text { Communication and } \\
\text { Advocacy }\end{array}$ & 1 & 2 & 3 & 4 & 5 & Mean & Rank \\
\hline $\begin{array}{l}\text { Age, gender and size of } \\
\text { family }\end{array}$ & 5.8 & 4.2 & 10 & 43.3 & 36.7 & 3.97 & 1 \\
\hline Government's support & 3.3 & 15 & 26.7 & 37.5 & 17.5 & 3.51 & 8 \\
\hline Social economic aspects & 4.2 & 5 & 16.7 & 44.2 & 30 & 3.91 & 2 \\
\hline Policy implementation & 1.7 & 16.7 & 25 & 32.5 & 24.2 & 3.61 & 7 \\
\hline Intermediaries formation & 6.7 & 4.2 & 15.8 & 44.2 & 29.2 & 3.85 & 3 \\
\hline Advertising campaigns & 5.8 & 10 & 22.5 & 35 & 26.7 & 3.67 & 5 \\
\hline $\begin{array}{l}\text { Agent and consumers } \\
\text { relationship }\end{array}$ & 7.5 & 3.3 & 18.3 & 35 & 35.8 & 3.42 & 9 \\
\hline Marketing approaches & 4.2 & 6.7 & 27.5 & 46.7 & 15 & 3.62 & 6 \\
\hline Personal interaction & 0.8 & 5.8 & 23.3 & 47.5 & 22.5 & 3.85 & 3 \\
\hline Innovative services & 6.7 & 6.7 & 20 & 30 & 36.7 & 3.84 & 4 \\
\hline
\end{tabular}

Respondents are asked to rank on a scale from 5 to 1 , where 5 indicates strongly agree, 4 indicates agree, 3 indicates very less likely agree, 2 indicates disagree and 1 indicates strongly disagree. The table presents the percentage of respondents, mean value and their rank.

In this regard, general public are asked to identify the components which impacts public awareness on life insurance policy. As is evident from table 1.6, Age, gender and size of family, social economic aspects, intermediaries' formation and personal interaction are four strongly agreed public awareness impacting life insurance policy. 
This table reveals that four of the ten Communication and advocacy components have been ranked 3.85 or more. The important note is that a large number of respondents agree on the fact that age, gender and size of the family members influence the life insurance most.

In a same way, the table 1.7 displays different criteria under risk and benefits in action along with their mean value and ranking. The mean score is calculated as follows: Mean value $=(5.8 * 1+3.3 * 2+19.2 * 3+45.8 * 4+25.8 * 5) / 100$, and so on

Table 1.7: Risk and Benefits in Action

Percentage of response within each

rank

\begin{tabular}{|l|r|r|r|r|r|r|r|}
\hline Risk and Benefits in Action & 1 & 2 & 3 & 4 & 5 & Mean & Rank \\
\hline WOM on benefits & 5.8 & 3.3 & 19.2 & 45.8 & 25.8 & 3.82 & 1 \\
\hline Protection tool & 0.8 & 8.3 & 36.7 & 34.2 & 20 & 3.64 & 7 \\
\hline Tax benefits & 2.5 & 2.5 & 26.7 & 51.7 & 16.7 & 3.78 & 2 \\
\hline Risk realization & 3.3 & 8.3 & 33.3 & 35.8 & 19.2 & 3.6 & 6 \\
\hline Small holder investment & 3.3 & 5.8 & 34.2 & 36.7 & 20 & 3.64 & 7 \\
\hline Family support & 5 & 10.8 & 25.8 & 40.8 & 17.5 & 3.56 & 8 \\
\hline Wealth creation & 1.7 & 11.7 & 22.5 & 40 & 24.2 & 3.73 & 3 \\
\hline Life insurance provides & & & & & & & \\
security & 5.8 & 4.2 & 30 & 40.8 & 20 & 3.67 & 4 \\
\hline Market inflation & 5 & 4.2 & 30 & 40.8 & 20 & 3.66 & 5 \\
\hline Better market value & 9.2 & 12.5 & 22.5 & 36.7 & 19.2 & 3.44 & 9 \\
\hline
\end{tabular}

Respondents are asked to rank on a scale from 5 to 1 , where 5 indicates strongly agree, 4 indicates agree, 3 indicates very less likely agree, 2 indicates disagree and 1 indicates strongly disagree. The table presents the percentage of respondents, mean value and their rank.

In this regard, general public are asked to identify the components which impact public awareness on life insurance policy. As is evident from table 1.7, WOM on benefits, tax benefits, and wealth creation are three strongly agreed public awareness 
impacting insurance policy. This table reveals that three of the ten risk and benefits in action components have been ranked 3.73 or more. The important note is that a large number of respondents agrees on the fact that WOM (Word of Mouth) on benefits of spending on insurance policy as a means of future returns impacts the general public awareness of life insurance the most.

\section{Discussion}

Generally speaking, there are rumors that the world of insurance is lacking general awareness to appeal a greater spectrum of insurance coverage globally. It has also been generally considered that the people would not go for buying insurance policies unless they face certain losses in their lives. In this respect, understanding the value of life insurance on human livelihood has emerged as a crucial global issue today. In this respect, different studies have been conducted from time to time in different parts of the world and there have been varying research findings.

Raju and Mohan (2011) have observed that nowadays customers are getting educated by media and are always in search of the best product quality and brand name. Likewise, the present researcher also focused on various media aspects such as advertisement, agents, recommendation and others impacting the awareness about life insurance.

On the basis of overall present study, the researcher would like to conclude that--

1. In spite of the immense benefits and security provided by the life insurance, public awareness regarding it is low.

2. Insurance awareness is positively affected by educational level of attainment whereas it is statistically independent to gender, income and professional line of involvement.

3. Since, media usage by females is more, they are more aware about life insurance through media than males. 


\section{REFERENCES}

Browne, M. J., \& Kim, K.. (1993). An International Analysis of Life Insurance Demand. The Journal of Risk and Insurance, 60(4), 616-634. http://doi.org/10.2307/253382.

Dar, A. A. (2011). Awareness of Life Insurance-A study of Jammu and Kashmir state. International Journal in Multidisciplinary and Academic Research, 1(3).

Ghosh, A. (2013). Does life insurance activity promote economic development in India: An empirical analysis. Journal of Asia Business Studies, 7(1), 31-43.

Government of Nepal.(GON). (2003). Insurance Act, 2003.Kathmandu.

Gurung, J. B. (2012). Insurance and Its Business in Nepal. Journal of Nepalese Business Studies, 7(1), 70-79.

Jain, D., \& Goyal, N. (2012). An Empirical Study of the Level of awareness towards various rights and duties among the insured households in Rajasthan, India. Researchers World, 3(3), 40.

Kakar, P., \& Shukla, R. (2010).The determinants of demand for life insurance in an emerging economy-India. Margin: The Journal of Applied Economic Research, 4(1), 49-77.

Li, D., Moshirian, F., Nguyen, P., \& Wee, T.. (2007). The Demand for Life Insurance in OECD Countries.The Journal of Risk and Insurance, 74(3), 637-652.

Rejda, G. E. (2011). Principles of risk management and insurance. Pearson Education India.

Sastry, V. S. (2010). Indian Insurance Data Issues. Paper presented by Director General, Insurance Regulatory and Development Authority, Hyderabad at the Seminar.

Schendler, B. (2005). How big can Apple get? Fortune, February 21, 2005, pp. 66 73. In Robbins, S. P., Judge, T. A., \& Sanghi, S. (2009). Organizational behavior. (13 ${ }^{\text {th }}$ ed.). New Delhi: Pearson Education. 